\title{
PENGALAMAN PASIEN COVID-19 YANG MENJALANI PERAWATAN DI RUMAH SAKIT DARURAT COVID WISMA ATLET JAKARTA
}

\author{
Diana Ekawaty \\ Universitas Muhammadiyah Jakarta \\ diana2021@gmail.com
}

\begin{abstract}
ABSTRAK
Penelitian ini bertujuan untuk menggali pengalaman pasien COVID-19 yang di rawat di Rumah Sakit Darurat COVID Wisma Atlet. Metode penelitian yang digunakan dalam penelitian ini adalah metode penelitian kualitatif dengan metode analisis tematik (thematic Analysis). Hasil penelitian ini menunjukkan ada 2 partisipan dengan kasus suspek dan 5 orang partisipan dengan kasus konfirmasi, adapun usia partisipan antara 26 sampai dengan 54 tahun. Pekerjaan partisipan sebanyak 4 orang karyawan, 2 orang tenaga medis dan 1 orang PNS. Dengan lama rata-rata waktu karantina 14 sampai dengan 38 hari rawat. Simpulan, penelitian ini menghasilkan 6 tema, yaitu: perubahan yang di alami pasien saat terdiagnosa COVID-19, perubahan yang di alami keluarga dan lingkungan anggota keluarga yang terdiagnosis COVID-19, sumber informasi untuk melakukan perawatan, sikap tenaga kesehatan yang melakukan perawatan, gambaran perasaan pasien selama dirawat, harapan pasien COVID-19 yang di rawat di RSDC Wisma Atlet.
\end{abstract}

Kata Kunci : COVID-19, Rumah Sakit Darurat COVID Wisma Atlet Jakarta, Karantina, Pengalaman

\begin{abstract}
This study aims to explore the experiences of COVID-19 patients treated at the Wisma Atlet COVID-19 Emergency Hospital. The research method used in this study is a qualitative research method with thematic analysis methods. This study showed that there were 2 participants with suspected cases and 5 participants with confirmed cases, while the age of participants was between 26 to 54 years. The participants' occupations are four employees, two medical personnel, and one civil servant with an average quarantine time of 14 to 38 days of care. In conclusion, This study resulted in 6 themes, namely: changes experienced by patients when diagnosed with COVID-19, changes experienced by the family and environment of family members diagnosed with COVID-19, sources of information for treatment, attitudes of health workers who carry out treatment, description of patient feelings. while being treated, the hope of COVID-19 patients being treated at the Wisma Atlet RSDC.
\end{abstract}

Keywords: COVID-19, Wisma Athlete Jakarta Emergency Hospital, Quarantine, Experience 


\section{PENDAHULUAN}

SARS-CoV-2 merupakan coronavirus jenis baru yang belum pernah diidentifikasi sebelumnya pada manusia. COVID-19 ini dapat menimbulkan gangguan pernafasan akut seperti demam, batuk dan sesak nafas, dengan masa inkubasi rata-rata 5-6 hari dengan masa inkubasi terpanjang 14 hari. Pada kasus yang berat dapat menyebabkan pneumonia, sindrom pernafasan akut, gagal ginjal dan bahkan kematian (Kementerian Kesehatan, 2020).

Covid-19 merupakan virus jenis baru yang ditemukan pada tahun 2019 dan belum pernah ditemukan menyerang manusia sebelumnya (WHO, 2020; Zulva, 2019). Covid-19 adalah penyakit menular yang disebabkan oleh Sindrom Pernafasan Akut Coronavirus 2 (Severe Acute Respiratory Syndrome Coronavirus 2 atau SARS-CoV02) (Setiawan, 2020). WHO menyatakan virus corona sebagai pandemi pada 11 Maret 2020, dan virus ini menyebar dengan sangat cepat (Moana, 2020). Status pandemi atau epidemi global menunjukkan bahwa penyebaran Covid-19 sangat cepat.

Indonesia melaporkan kasus pertama pada bulan Maret. Sampai Juli 2020 Kementerian Kesehatan melaporkan 70.736 kasus konfirmasi COVID-19 dengan 3.417 kasus meninggal (CFR 4,8\%). Di Jakarta sendiri kasus konfirmasi pada Bulan agustus 2020 mencapai25.287 (Kementerian Kesehatan, 2020a). Untuk Kasus Suspek, Probable dan Konfirmasi, pasien-pasien ini memerlukan perawatan isolasi baik isolasi mandiri maupun isolasi di fasilitas kesehatan yang merupakan fasilitas rujukan COVID.

Wang et al., (2020) Dijelaskan pula bahwa dampak pandemi Covid-19 telah menimbulkan banyak kerugian seperti hambatan fisik, ketimpangan ekonomi, ketimpangan sosial dan gangguan jiwa. Saat terinfeksi virus corona ini, kondisi psikologis yang dialami masyarakat akan merasa cemas (Fitria et al., 2020). Huang et al., (2020) menjelaskan, gangguan jiwa yang terjadi selama pandemi Covid-19 adalah kecemasan, ketakutan, stres, depresi, panik, sedih, depresi, marah, dan penyangkalan.

Perawat dan Dokter adalah garda terdepan dalam penanggulangan pandemi ini. Mereka secara otomatis bergerak dengan cekatan dan tanggap dalam penanganan pasien COVID 19 ini. Perawat melakukan triase dan melakukan screening pada pasien COVID 19. Mulai dari identifikasi pasien, keluarga, tempat tinggal dan riwayat kontak dengan orang lain serta tracking riwayat perjalanan pasien dari Zona Merah yang ada di Indonesia. Zona Merah adalah sebutan untuk kota yang sudah terindikasi adanya pasien positif COVID 19. Perawat berupaya dengan baik untuk melakukan pendekatan ke pasien dalam menentukan strategi perawatan selanjutnya. Berbagai kejadian yang penuh dengan stress membuat tugas ini menjadi tidak mudah karena minimalnya informasi, belum tetapnya standar prosedur Rumah Sakit dari Kementrian Kesehatan yang membuat banyak tenaga medis dan perawat menjadi bingung. Berbagai konflik akhirnya muncul membuat system pelayanan dapat terpengaruh (Marwiati et al., 2021).

Rumah Sakit Darurat COVID (RSDC) Wisma Atlet merupakan Rumah Sakit yang dinyatakan sebagai Rumah Sakit Karantina dengan jumlah kasus pada bulan Agustus mencapai 1.421 pasien.

\section{METODE PENELITIAN}

Metode penelitian yang digunakan dalam penelitian ini adalah metode penelitian kualitatif dengan metode analisis tematik (thematic Analysis). 


\section{Tempat dan Waktu Penelitian}

Penelitian ini akan dilaksanakan di Rumah Sakit Darurat Covid (RSDC) Wisma Atlet Jakarta.

\section{Etika Penelitian}

Peneliti memberikan lembar informed concent dalam mencari partisipan, selama penelitian dan sesudah melakukan penelitian privacy partisipan harus tetap terjaga, semua partisipan harus di berlakukan sama, bila diperlukan nama partisipan di ganti dengan nomor (anominity).

Pertimbangan etik di gunakan untuk mencegah terjadinya masalah etik dalam penelitian yang di gunakan adalah dengan memiliki berbagai macam prinsip yaitu: self determinan, privacy dan dignity, confidentiality dan protection from discomfort.

\section{Alat Pengumpulan Data}

Alat bantu pengumpulan data yang digunakan dalam penelitian ini adalah, peneliti sendiri, Pedoman wawancara, field notes selanjutnya alat perekam suara (voice recorder).

\section{Proses Analisis Data}

Analisa diawali dengan membaca transkip dan catatan lapangan yang berulang, sampai peneliti dapat memahami data dengan baik.

\section{HASIL PENELITIAN}

\section{Gambaran Karakteristik Partisipan}

Partisipan dalam penelitian ini berjumlah 7 orang yang sesuai dengan kriteria inklusi bahwa partisipan adalah pasien COVID-19, baik kasus Suspek, Probable maupun kasus Konfirmasi, dimana ada 2 partisipan dengan kasus suspek dan 5 orang partisipan dengan kasus konfirmasi, adapun usia partisipan antara 26 sampai dengan 54 tahun. Pekerjaan partisipan sebanyak 4 orang karyawan, 2 orang tenaga medis dan 1 orang PNS. Dengan lama rata-rata waktu karantina 14 sampai dengan 38 hari rawat.

\section{Analisis Tematik}

Berdasarkan hasil wawancara mendalam serta observasi dengan menggunakan catatan lapangan selama proses pengambilan data ini, maka peneliti melakukan analisis data dengan menggunakan thematic analysis. Penelitian ini menghasilkan 6 tema, yaitu: Perubahan yang di alami pasien saat terdiagnosa COVID-19, perubahan yang di alami keluarga dan lingkungan anggota keluarga yang terdiagnosis COVID-19, sumber informasi untuk melakukan perawatan di RSDC Wisma Atlet, sikap tenaga kesehatan yang melakukan perawatan di RSDC Wisma Atlet, gambaran perasaan pasien selama di RSDC Wisma Atlet, harapan pasien COVID-19 yang di rawat di RSDC Wisma Atlet. Masingmasing tema akan di uraikan satu persatu sebagai berikut:

\section{Tema 1. Perubahan yang Dialami Pasien saat Terdiagnosis COVID-19}

Sub tema yaitu perubahan psikologis yang dialami oleh partisipan laki-laki dan perempuan, hampir semua dengan keluhan yang sama. Sub tema yaitu kecemasan, kekhawatiran dan ketakutan. kategori dampak psikologis pasien COVID-19.

"wah saya tidak bisa bercerita ya,, takut, khawatir semua menumpuk jadi satu"(P2)

"nangis, bingung mau bagaimana,,,"(P4) 


\section{Tema 2. Perubahan yang Dialami Keluarga dan Lingkungan Anggota Keluarga yang Terdiagnosis COVID-19}

Sub tema respon keluarga dan respon lingkungan. kategori yaitu dampak psikologis keluarga pasien yang terdiagnosa COVID-19 dan stigma lingungan.

"respon mereka ya hampir sama dengan saya, mereka terlihat tertekan dan stress"(P2)

" mereka sedih dan khawatir, suami saya terlihat sangat khawatir dan tertekan tapi berusaha tegar di depan saya”(P3)

"suamiku bingung, galau harus bagaimana ya"(P4)

“ istri saya menangis, sedih"(P5)

Sedangkan pada perubahan yang dialami keluarga dan lingkungan anggota keluarga yang terdiagnosis COVID-19 yang merupakan respon lingkungan.

" kalau orang di sekitar saya saat itu hanya teman-teman saya saja dan mereka sedih juga siyy denger saya positif dan mereka memberikan dukungan buat saya"(P1)

"sikap orang sekitar siyy biasa saja karena saya dan keluarga tidak pernah lapor $k l$ saya positif COVID”(P4)

\section{Tema 3. Sumber Informasi untuk Melakukan Perawatan}

Sub tema keputusan melakukan perawatan di RSDC Wisma Atlet. Sub-sub tema yaitu petugas medis, keluarga dan teman. Kategori yaitu pemberi informasi.

“ awalnya saya bingung mau dirawat dimana, trus dokter yang bertugas di POLI ODP menyarankan saya untuk ke wisma atlet saja karna sudah ada beberapa tementemen yang di rawat disana, akhirnya saya memutuskan untuk ke Wisma Atlet"(P1)

"suami saya yang menganjurkan saya untuk ke wisma atlet untuk mendapatkan perawatan disana karena khawatir dengan orangtua saya yang sudah usia dan komorbid"(P3)

\section{Tema 4. Sikap Tenaga Kesehatan yang Melakukan Perawatan}

Sub tema yaitu respon tim medis dan Informasi yang diberikan oleh tim medis. Subsub tema yaitu responnya cepat, tanggap, baik, welcome dan sigap. Pada Informasi yang diberikan oleh tim medis sub-sub temanya adalah diberikan oleh petugas medis dan melalui alat informasi lainnya.

" tim medis disana cukup baik dan sigap"(P3)

" respon mereka sangat baik dan cepat"(P6)

Sikap Tenaga Kesehatan yang melakukan perawatan di RSDC Wisma Atlet yaitu informasi yang diberikan oleh tim medis.

"kami datang langsung di wawancarai dan diberikan informasi serta penjelasan tentang perawatan isolasi mandiri di wisma atlet oleh petugas medisnya" (P3)

" di informasikan dari pertama kali kita masuk waktu di pintu penerimaan pasien sudah ada banner tentang cara isolasi mandirinya dan diberitahu juga oleh petugasnya” (P7)

\section{Tema 5. Gambaran Perasaan Pasien Selama Dirawat}

Sub tema yaitu Gambaran kondisi pasien, aktifitas, lingkungan, komunikasi antar sesama pasien dan fasilitas. Sub-sub tema yaitu sehat dan bergejala ringan, olahraga dan berjemur, lingkungan yang awalnya kotor, komunikasi lewat whatsapp dan fasilitas yang memadai. 
“ kondisi pasien di sana rata-rata sama dengan saya, mereka hanya gejala ringan jadi bisa isolasi mandiri"'(P1)

" rata-rata siyy mereka seperti orang yang sehat ya, bisa beraktifitas,tidak ada sakit yang berat paling hanya batuk ringan" (P2)

Gambaran perasaan pasien selama dirawat di RSDC Wisma Atlet yang menggambarkan aktifitas pasien pada pagi hari selama di rawat di RSDC Wisma Atlet.

" saya suka olahraga bersama teman saya yang kebetulan di rawat juga di sana, kemudian berjemur dan saling berbagi pengalaman,, saya juga berdoa supaya saya bisa cepat pulang kerumah" $(P 2)$

“nonton korea, olahraga, berjemur"(P5)

Gambaran perasaan pasien selama dirawat di RSDC Wisma Atlet yang menggambarkan lingkungan pasien selama di rawat di RSDC Wisma Atlet.

"pada awal kami sampai kondisi ruangan agak kotor sehingga kami harus membersihkannya dulu”(P3)

"pas baru datang siyy memamg kotor banget mungkin karena tadinya ruangan yang lama tidak dipakai”'(P4)

Gambaran perasaan pasien selama dirawat di RSDC Wisma Atlet yang menggambarkan komunikasi antar sesama pasien selama di rawat di RSDC Wisma Atlet.

" saya siyy hanya komunikasi sama temen sekamar, selebihnya kalo mau komunikasi dengan pasien lain lain menggunakan fasilitas WA grup lantai”(P1)

"biasanya komunikasi lewat WAG yang di sediakan atau difasilitasi di setiap lantai oleh petugas medis"(P3)

Gambaran perasaan pasien selama di rawat di RSDC Wisma Atlet yang menggambarkan fasilitas di RSDC Wisma Atlet.

" perawatannya siyy cukup lumayan,fasilitasnya juga cukup memadai ada kamar mandi disetiap ruangan dan AC di setiap kamar" (P2)

" perawatannya baik, fasilitas cukup memadai walaupun peralatannya tidak selengkap rumah sakit, tapi untuk IGD cukup baik”(P6)

\section{Tema 6. Harapan Pasien COVID-19 yang Dirawat}

Sub tema yaitu hasil swab pasien dan peningkatan pelayanan. Sub-sub tema yaitu hasil swab bisa lebih cepat dan pelayanan lebih baik. Harapan Pasien COVID-19 yang Dirawat di RSDC Wisma Atlet tentang perbaikan hasil swab.

" harapan saya bisa lebih baik lagi terutama untuk hasil pemeriksaan Swab”(P1)

" harapannya pelayanan di wisma atlet bisa lebih baik lagi dan hasil pemeriksaaan juga lebih cepat sehingga pasien tidak perlu sampai berlama-lama disana hanya untuk menunggu hasil swab"(P3)

\section{PEMBAHASAN}

\section{TEMA 1: Perubahan yang Dialami pada saat Terdiagnosis COVID-19}

Dalam penelitian ini ditemukan bahwa terjadi perubahan Psikologis pasien. Perubahan psikologis sangat terlihat jelas pada pasien-pasien tersebut seperti cemas, sedih, takut, khawatir dan bingung. Temuan sejalan bahwa orang cenderung merasa cemas dan tidak aman saat perubahan lingkungan. Dalam kasus penyakit menular wabah, bila 
penyebab atau perkembangan penyakit dan hasilnya tidak jelas, rumor berkembang dan sikap tertutup terjadi (Ren et al., 2020).

\section{TEMA 2: Perubahan yang Dialami Keluarga dan Lingkungan saat Anggota Keluarga Terdiagnosis COVID-19}

Tema ini menjelaskan bagaimana perasaan keluarga saat memngetahui bahwa anggota keluarganya terdiagnosis dengan COVID19. Dalam hal ini perasaan yang di rasakan juga sama dengan pasiennya, merasa cemas, sedih, bingung dan tentunya khawatir akan kesehatan dan keselamatan anggota keluarganya. Hal sama yang di katakan (Usher et al., 2020) Individu, keluarga, dan komunitas mengalami perasaan putus asa, putus asa, sedih, kehilangan, dan kehilangan tujuan yang dalam karena dari pandemi (Levin, 2019). Selain respon keluarga, respon lingkungan juga perlu diperhatikan karena menurut (Ren et al., 2020). Secara psikologis, ketika lingkungan hidup berubah, orang merasa tidak aman, gelisah, dan cemas. Ketika penyebab epidemi tidak jelas, sikap berpikiran tertutup dan rumor sering berkembang. Orang-orang yang tidak bersalah di Wuhan menjadi sasaran dan disalahkan secara tidak adil tingkat nasional, dan hal yang sama terjadi pada orang Tionghoa secara internasional.

Sylvie Briand berkata, "Ketakutan dan stigma berjalan seiring dan ketika orang takut, mereka cenderung menstigmatisasi beberapa kompok. Namun pada penelitian ini pengalaman partisipan terhadap respon lingkungan cukup baik 5 dari 7 partisipan mengatakan lingkungan sekitar cukup baik dan tidak ada diskriminasi.

\section{TEMA 3: Sumber Informasi untuk Melakukan Perawatan}

Tema ini menjelaskan tentang bagaimana informasi di dapatkan oleh pasien sehingga pasien dapat melakukan perawatan di RSDC Wisma Atlet. Petugas kesehatan, keluarga dan teman adalah sumber informasi yang dapat diterima oleh pasien yang sedang mengalami masalah psikologis karena terdiagnosis COVID-19, karena mereka adalah orang-orang terdekat yang sangat di perlukan untuk proses kesembuhan pasien.

\section{TEMA 4: Sikap Tenaga Kesehatan dalam Melakukan Perawatan}

Pada tema ini membahas tentang bagaimana respon petugas medis dalam memberikan pelayanan terhadap pasien-pasien COVID-19 serta informasi apa saja yang diberikan kepada pasien yang akan menjalani perawatan di RSDC Wisma Atlet. Respon petugas kesehatan yang baik serta pemberian informasi yang tepat dapat membantu pemulihan pasien. Hal ini seperti yang di katakan (Ransing et al., 2020) bahwa Informasi adalah hal yang utama tentang COVID-19 terutama kesehatan mental preventif, promosi kesehatan mental, dan pengawasan kesehatan mental.

Pengalaman pertama ini membuat perawat menjadi tegang, cemas akan tetapi disatu sisi yang lain tetap harus memberikan perawatan yang adekuat dan komphrehensif dan mempertahankan kehidupan pasien. Hal ini dikarenakan penyakit COVID 19 adalah penyakit baru yang belum diketahui metode yang efektif untuk penatalaksanaanya (Xu et al., 2020; Liu et al., 2020; Wang et al., 2020). Kondisi pandemi yang ditetapkan oleh WHO membuat kondisi dan situasi yang ada dipelayanan kesehatan membuat semua orang mengalami kecemasan yang berlebih dan kemampuan untuk memanajemen stress yang dapat muncul sehingga perawat bisa mengatasi permasalahan stressor dalam diri sendiri (Wang et al., 2020; Tan et al., 2020). 


\section{TEMA 5: Gambaran Perasaan Pasien selama Dirawat}

Pada tema ini menggambarkan bagaimana kondisi pasien, aktifitas pasien selama berada di RSDC Wisma Atlet, lingkungan di RSDC Wisma Atlet, Komunikasi antar pasien serta fasilitas yang ada di Wisma Atlet. Gambaran kondisi pasien pada penelitian ini bahwa pasien-pasien yang berada di wisma atlet merupakan pasien-pasien dengan gejala ringan sehingga pasien-pasien tampak terlihat sehat, hal ini sesuai dengan (Kementerian Kesehatan, 2020b) .

\section{TEMA 6: Harapan Pasien COVID-19 yang Dirawat}

Pada tema ini membahas tentang harapan dan keinginan dari pasien baik yang masih di rawat maupun yang pernah menjalani perawatan di RSDC Wisma Atlet, tentang bagaimana meningkatkan fasilitas di wisma atlet terutama hasil pemeriksaan Swab yang sampai saat ini masih sangat lama. Menurut (Kementerian Kesehatan, 2020) pada kasus suspek yang melakukan isolasi mandiri, pemantauan dilakukan oleh petugas kesehatan dan pemantauan dapat dihentikan apabila hasil pemeriksaaan RT-PCR selama 2 hari berturutturut dengan selang waktu > 24 Jam menunjukan hasil negatif. Sedangkan di Wisma Atlet hasil pemeriksaan swab cukup lama sekitar 7 sampai dengan 14 hari atau lebih, yang pada akhirnya akan memperpanjang masa isolasi pasien di RSDC Wisma Atlet dan kemungkinan untuk terpapar menjadi kasus konfirmasi pada pasien-pasien yang hanya suspek sangat tinggi.

\section{SIMPULAN}

Penelitian ini menghasilkan 6 tema, yaitu: perubahan yang di alami pasien saat terdiagnosa COVID-19, perubahan yang di alami keluarga dan lingkungan anggota keluarga yang terdiagnosis COVID-19, sumber informasi untuk melakukan perawatan, sikap tenaga kesehatan yang melakukan perawatan, gambaran perasaan pasien selama dirawat, harapan pasien COVID-19 yang di rawat di RSDC Wisma Atlet.

\section{SARAN}

Pendekatan Psikologis perlu diterapkan perawat sebagai dasar yang cukup dalam memberikan asuhan keperawatan yang optimal bagi pasien COVID-19.

\section{DAFTAR PUSTAKA}

Fitria, L., Neviyarni, N., \& Karneli, Y. (2020). Cognitive Behavior Therapy Counseling untuk Mengatasi Anxiety dalam Masa Pandemi Covid-19. Al-Irsyad: Jurnal Pendidikan Dan Konseling, 10(1), 23-29. http://jurnal.uinsu.ac.id/index.php/alirsyad/article/viewFile/7651/3538

Huang, C., Wang, Y., Li, X., Ren, L., Zhao, J., Hu, Y., Zhang, L., Fan, G., Xu, J., Gu, X., Cheng, Z., Yu, T., Xia, J., Wei, Y., Wu, W., Xie, X., Yin, W., Li, H., Liu, M., \& Cao, B. (2020). Clinical Features of Patients Infected with 2019 Novel Coronavirus in Wuhan, China. The Lancet, 395(10223), 497-506. https://doi.org/10.1016/S01406736(20)30183-5

Kementerian Kesehatan. (2020a). COVID-19 dalam Angka. https://covid19.kemkes.go.id/situasi-infeksi-emerging/info-corona-virus/situasiterkini-perkembangan-coronavirus-disease-covid-19-

Kementerian Kesehatan. (2020b). Pedoman Pencegahan Dan Pengendalian Coronavirus Disease (COVID-19). In Kemenkes (Vol. 5). https://doi.org/10.33654/math.v4i0.299 
Liu, Q., Luo, D., Haase, J. E., Guo, Q., Wang, X. Q., \& Liu S. (2020). The Experiences of Health-Care Providers during the COVID-19 Crisis in CHINA: A Qualitative Study. Lancet Glob Heal, 8(6), 790-8

Marwiati, M., Komsiyah, K., Indarti, D. (2021). Pengalaman Perawat IGD dalam Merawat Pasien Covid-19: Studi Kualitatif di IGD Rumah Sakit di Semarang. Jurnal Pengabdian kepada Masyarakat UNSIQ, 8(2), 163-167. https://ojs.unsiq.ac.id/index.php/ppkm/article/download/1784/1095/

Moana, N. (2020). Konsep Isolasi dalam Jaringan Sosial untuk Meminimalisasi Efek Contagious (Kasus Penyebaran Virus Corona di Indonesia). Jurnal Sosial Humaniora Terapan, 2(2), 117-125. https://doi.org/10.7454/jsht.v2i2.86

Ransing, R., Adiukwu, F., Pereira-Sanchez, V., Ramalho, R., Orsolini, L., Teixeira, A. L. S., Gonzalez-Diaz, J. M., da Costa, M. P., Soler-Vidal, J., Bytyçi, D. G., El Hayek, S., Larnaout, A., Shalbafan, M., Syarif, Z., Nofal, M., \& Kundadak, G. K. (2020). Mental Health Interventions during the COVID-19 Pandemic: A Conceptual Framework by Early Career Psychiatrists. Asian Journal of Psychiatry, 51(April), 102085. https://doi.org/10.1016/j.ajp.2020.102085

Ren, S. Y., Gao, R. D., \& Chen, Y. L. (2020). Fear Can be More Harmful than the Severe Acute Respiratory Syndrome Coronavirus 2 in Controlling the Corona Virus Disease 2019 Epidemic. World Journal of Clinical Cases, 8(4), 652-657. https://doi.org/10.12998/wjcc.v8.i4.652

Setiawan, A. R. (2020). Lembar Kegiatan Literasi Saintifik untuk Pembelajaran Jarak Jauh Topik Penyakit Coronavirus 2019 (COVID-19). Edukatif: Jurnal Ilmu Pendidikan, 2(1), 28-37. https://doi.org/10.31004/edukatif.v2i1.80

Tan, W., Hao, F., McIntyre, R. S., Jiang, L., Jiang, X., \& Zhang, L. (2020). Is Returning to Work during the COVID-19 Pandemic Stressful? A Study on Immediate Mental Health Status and Psychoneuroimmunity Prevention Measures of CHINESE Workforce. Brain Behav Immun

Usher, K., Durkin, J., \& Bhullar, N. (2020). The COVID-19 Pandemic and Mental Health Impacts. International Journal of Mental Health Nursing, 29(3), 315-318. https://doi.org/10.1111/inm.12726

Wang, C., Pan, R., Wan, X., Tan, Y., Xu, L., \& McIntyre, R. S. (2020). A Longitudinal Study on the Mental Health of General Population during the COVID-19 Epidemic in China. Brain Behav Immun

Wang, Z., Qiang, W., \& Ke, H. (2020). A Handbook of 2019-nCoV Pneumonia Control and Prevention. In Hubei Science and technology press. http://fpmpam.org/files/Handbook_2019nCoV.pdf

WHO. (2020). Coronavirus Disease 2019. Coronavirus Disease (COVID-19) Situation Report, 8(6), e01218. https://doi.org/10.1213/xaa.0000000000001218

WHO. (2020). Report of the WHO-China Joint Mission on Coronavirus Disease 2019 (COVID-19). The WHO-China Joint Mission on Coronavirus Disease 2019, 2019(February), 16-24. https://www.who.int/docs/default-source/coronaviruse/whochina-joint-mission-on-covid-19-final-report.pdf

Xu, K., Cai, H., Shen, Y., Ni, Q., Chen, Y., \& Hu, S. (2020). Management of corona virus Disease19 (COVID-19): the Zhejiang Experience. Zhejiang Da Хие Хие Вао Yi Хие Ban, 49(1)

Zulva, T. N. I. (2019). Covid-19 dan Kecenderungan Psikosomatis. Journal of Chemical Information and Modeling, 53(9), 1689-1699 